\title{
Barn Owl pellets (Aves: Tyto furcata) reveal a higher mammalian richness in the Restinga de Jurubatiba National Park, Southeastern Brazil
}

\author{
Hudson de Macedo Lemos ${ }^{1,2}$, Carina Azevedo Oliveira Silva ${ }^{1}$, Fabio de Mello Patiu ${ }^{1}$ \& \\ Pablo Rodrigues Gonçalves ${ }^{1}$ \\ ${ }^{1}$ Universidade Federal do Rio de Janeiro, Núcleo em Ecologia e Desenvolvimento Sócio-Ambiental \\ de Macaé, Av. São José do Barreto, 764, CEP 27965-045, Bairro Barreto, Macaé, RJ, Brazil. \\ ${ }^{2}$ Corresponding author: Hudson de Macedo Lemos, e-mail: hudson.ml@gmail.com
}

LEMOS, H.M., SILVA, C.A.O., PATIU, F.M., GONÇALVES, P.R. Barn Owl pellets (Aves: Tyto furcata) reveal a higher mammalian richness in the Restinga de Jurubatiba National Park, Southeastern Brazil. Biota Neotropica. 15(2): e20140121. http://dx.doi.org/10.1590/1676-06032015012114

\begin{abstract}
The northern coast of the state of Rio de Janeiro harbors the largest coastal sandy plains (restingas) of southeastern Brazil, severely threatened due to recent human occupation. In this context, mammal inventories becomes urgent to support biodiversity conservation and management policies. This paper aims to update the knowledge on the mammalian species richness of Restinga de Jurubatiba National Park by analyzing pellets of the Barn owl Tyto furcata. The analyses of 4745 mammalian bone fragments (1739 individuals) revealed the occurrence of 17 species belonging to the orders Rodentia ( $9 \mathrm{spp}$.), Didelphimorphia (2 spp.) and Chiroptera (6 spp.). The rodents Mus musculus and Cerradomys goytaca accounted for $77.2 \%$ of the total individuals preyed, suggesting that the Barn owl hunts in both disturbed and natural open shrub formations. A compilation of previous records, together with those provided in the present study, indicates the occurrence of 44 species of mammals in the Restinga de Jurubatiba National Park, of which six (13.6\%) were exclusively detected in pellets. These new records include species adapted to open formations of the interior of Brazil that were not previously reported in restingas on the basis of voucher-specimens, such as the rodents Necromys lasiurus and Calomys tener, the latter being recorded for the first time in the littoral of Rio de Janeiro state. This study underscores the importance of owl pellet analysis as a complementary and indispensable method for inventorying mammals. The results highlight the Restinga de Jurubatiba National Park as one of the restingas in Southeastern Brazil with the highest number of mammal species.
\end{abstract}

Keywords: restingas, species richness, inventory methods, new records, geographic distribution.

LEMOS, H.M., SILVA, C.A.O., PATIU, F.M., GONÇALVES, P.R. Pelotas de coruja suindara (Aves: Tyto furcata) revelam uma elevada riqueza de mamiferos no Parque Nacional da Restinga de Jurubatiba, Sudeste do Brasil. Biota Neotropica. 15(2): e20140121. http://dx.doi.org/10.1590/1676-06032015012114

Resumo: O litoral norte do estado do Rio de Janeiro possui a maior planície deltaica recoberta por restingas do sudeste brasileiro, porém sob intensa ameaça devido à ocupação humana recente. Neste contexto, a realização de inventários torna-se urgente para fortalecer políticas de manejo e conservação ambiental. Esse trabalho teve como objetivo complementar inventários mastofaunísticos do Parque Nacional da Restinga de Jurubatiba através da utilização de pelotas da coruja suindara Tyto furcata. A análise de 4745 fragmentos ósseos de mamíferos (1739 indivíduos) revelou a ocorrência de 17 espécies pertencentes às ordens Rodentia (9 spp.), Didelphimorphia (2 spp.) e Chiroptera (6 spp.). Os roedores Mus musculus e Cerradomys goytaca foram responsáveis por $77,2 \%$ do total de indivíduos predados, sugerindo que a suindara caça tanto em ambientes peridomiciliares perturbados como em formações naturais arbustivas da restinga. A compilação de registros anteriores com os fornecidos pelo presente estudo indica a ocorrência de 44 espécies de mamíferos no Parque Nacional da Restinga de Jurubatiba, dentre as quais seis (13.6\%) foram exclusivamente detectadas em pelotas. Dentre estes novos registros, destaca-se a presença de espécies adaptadas a formações abertas do interior do Brasil que não tinham sua ocorrência documentada em restingas a partir de espécimes-testemunho, como os roedores Necromys lasiurus e Calomys tener, esta última registrada pela primeira vez no litoral do estado do Rio de Janeiro. Esse estudo corrobora a importância das análises de pelotas de coruja como método complementar e imprescindível em inventários de mamíferos, além de destacar o Parque Nacional da Restinga de Jurubatiba como uma das restingas mais ricas em espécies de mamíferos do sudeste brasileiro.

Palavras-chave: restingas, riqueza de espécies, métodos de inventário, novos registros, distribuição geográfica. 


\section{Introduction}

Mammalian diversity in the Brazilian Atlantic forest is relatively high in comparison to those found in other biomes in Brazil, being distributed throughout a wide range of physiognomies that includes dense and humid forests to coastal sandy plains covered by shrublands and dry forests (Paglia et al. 2012). These coastal sandy plains, commonly termed restingas, are discontinuously distributed along the Brazilian littoral near river mouths or zones of past marine transgressions, harboring varied biotas, lagoons and vegetation types, some of which adapted to dry or arid conditions (Cerqueira 2000, Esteves 2011). Most restingas are intensively threatened by urban, rural and industrial occupation and development, especially in the northern littoral of Rio de Janeiro state, where most of the Brazilian petroleum exploitation has been based (Bergallo et al. 2009, Esteves 2011).

Despite recent transformations, the northern littoral of Rio de Janeiro state still harbors the most expressive restingas in Southeastern Brazil, with 14,860 hectares of these areas protected by the Restinga de Jurubatiba National Park (Rocha et al. 2007). Zoological studies on the mammals of this region have been carried out only recently but promptly reveal a rich mammalian fauna (Bergallo et al. 2004, Pessoa et al. 2010), with a number of new occurrences of bats, rodents and marsupials with poorly known distributions (Luz et al. 2011, Mangolin et al. 2007, Pessôa et al. 2010), and of recently described endemic species (Tavares et al. 2011). As many mammal species act as important seed dispersers, hosts, preys, predators and invasive taxa (Grenha et al. 2010, MartinsHatano et al. 2011, Raíces \& Bergallo 2010), basic knowledge on the composition of local mammalian faunas is important not only to fill in distribution gaps, but also to assess the integrity of ecological processes. Given the increasing impacts in the northern littoral of Rio de Janeiro state, such knowledge becomes timely and urgent in the Restinga de Jurubatiba National Park, which may serve as a reference in conservation and biogeographic studies of restingas owing to its large size, location and level of protection. However, reasonably complete mammal inventories are difficult to achieve even at local scales due to the rarity, difficult detection and varied ecology of species-rich groups, such as rodents, marsupials and bats, often requiring long-term combined use of different sampling methods (Umetsu et al. 2006).

Valuable information on the local abundance and richness of small mammals in several tropical ecosystems have been obtained from skull, mandibles and bone fragments found in Barn owl pellets (Tyto furcata, Strigidae) (Bonvicino \& Bezerra 2003, Scheibler \& Christoff 2007, Rocha et al. 2011). Barn owls are adapted to nocturnal-hunting in open areas (Taylor 1994), preying primarily on small mammals, many of which rarely recorded by usual trapping methods (Bonvicino \& Bezerra 2003). The undigested parts of their prey, such as bones and hairs, are regurgitated in the form of small pellets near their nests, and most mammalian skulls, mandibles and teeth can be taxonomically identified, providing a complementary assessment of the local small mammal species (Moojen 1943). Despite its advantages and low cost, the analysis of owl pellets has been rarely included in mammal inventories in restingas, especially in the Rio de Janeiro state, where most assessments have been exclusively based on live-trapping methods (Moura et al. 2008).
In this paper, we analyzed a collection of bone fragments recovered from Barn owl pellets in the Restinga de Jurubatiba National Park in order to update the mammal species richness and composition recorded in this region and to evaluate the complementarity of this type of evidence to local inventories, discussing the ecological and biogeographic implications of novel species records.

\section{Material and Methods}

This study was conducted in the Restinga de Jurubatiba National Park, located in the northern Rio de Janeiro littoral between latitudes $22^{\circ} 08^{\prime}$ and $22^{\circ} 19^{\prime} \mathrm{S}$ and longitudes $41^{\circ} 17^{\prime}$ and $41^{\circ} 43^{\prime} \mathrm{W}$, encompassing the municipalities of Quissamã, Carapebús and Macaé. The Park protects 14,860 hectares $(62.2 \%)$ of the largest continuous restinga remnant in Southeastern Brazil (23,884 hectares) (Rocha et al. 2004a, 2007), being the sole National Park exclusively devoted to the preservation of coastal sandy plain ecosystems. The climate is classified as tropical rainy (Aw of the Köppen system), generally exhibiting a rainy season between October and April and a dry season between May and September. The accumulated annual rainfall between 1992 and 2013 varied between $626.6 \mathrm{~mm}$ and $1593.6 \mathrm{~mm}$. The monthly temperature averages $21.6^{\circ} \mathrm{C}$ in June and $27.4^{\circ} \mathrm{C}$ in January (INMET 2014).

In August 2011 a nest of Tyto furcata was found in an abandoned rural habitation $\left(22^{\circ} 16^{\prime} 35^{\prime}\right.$ 'S, $\left.41^{\circ} 40^{\prime} 10^{\prime} \mathrm{W}, 5 \mathrm{~m}\right)$ located in an open shrub formation surrounded by several vegetation formations (dry forests, seasonally flooded forests, marshes and coconut plantations mixed with exotic grasses), all within the coastal sandy plain area. Several pellets and disaggregated bone fragments were collected at this occasion, but in November 2011 all the skeletal material found at the nesting site was collected with the aid of a shovel and broom, filling two 60L buckets. Since then, the accumulation of additional pellets was monitored each trimester, from February 2012 to March 2013.

All pellets and bone fragments collected were screened for small mammals separating them from hairs, arthropods and non-mammalian skeletal remains (birds, reptiles and amphibians). Species identifications were based on complete and fragmented skulls and mandibles. Identifiable skull fragments comprised parts of maxillary with or without teeth, zygomatic plates, interorbits and nearly complete skulls lacking few structures. Each skeletal element or bone fragment identified counted as one unit of the number of identified specimens (NISP), and we used the most commonly occurring bone fragment or element of a given taxon to estimate its minimal number of individuals (MNI), interpreted as a proxy of the taxon frequency in the pellet collection (Lyman 2008). Cranial and dental characters were compared to identified specimens housed at the mammal collections of NUPEM/UFRJ (NPM) and Museu Nacional (MN) at Universidade Federal do Rio de Janeiro, which contain relevant series of topotypes of Cerradomys goytaca Tavares, Pessôa and Gonçalves, 2011 and of voucher specimens (skins, skulls, tissues and cells) of other small mammal species with regional occurrence. In addition to direct comparisons with reference collections, we also studied original or emended cranial and dental descriptions of each taxon available in the taxonomic literature (Voss \& Carleton 1993, Steppan 1995, López-González 2005, Voss \& Jansa 2009, Tavares et al. 2011). We also compiled information 
on mammal species richness and composition in the Restinga de Jurubatiba National Park, revising previous inventory studies carried out by live-trapping, mistnets and other methods (Bergallo et al. 2004, Pessôa et al. 2010, Luz et al. 2011). All specimens identified in the pellets and analyzed in this study are deposited in the mammal collection of NUPEM/ UFRJ (lots NPM 176, 934-987).

We assessed completeness and sampling sufficiency of the pellet inventory by means of cumulative species curves. Two cumulative curves were constructed by rarefaction, one including all mammalian taxa identified in the owl pellets (Volant and non-volant) and the other including only nonvolant taxa. In both analyses the cumulative mean number of species expected by the number of sampled individuals and the respective unconditional variances were calculated (standarddeviation and 95\% confidence interval) (Colwell et al. 2012; Colwell 2013). The asymptotic behavior of the cumulative curves was examined in order to evaluate the completeness of species number estimates based on owl pellets. All cumulative curves and rarefaction procedures were performed on EstimateS 9.1 (Colwell 2013).

\section{Results}

Approximately $10 \mathrm{Kg}$ of material was collected in the Tyto furcata nesting site, containing 4745 mammalian bone fragments (specimens) of at least 1739 individuals belonging to 17 small mammal species of the orders Rodentia, Chiroptera and Didelphimorphia (Table 1). The order Rodentia was the most representative in both species number and relative frequency of individuals preyed, comprising nine species and $98 \%$ of the specimens identified in owl pellets, with Mus musculus and Cerradomys goytaca being by large the two most preyed species. The order Chiroptera was second to rodents in species number, represented by six species, but accounting for less than $1 \%$ of the specimens identified, with Carollia perspicillata and Eptesicus sp. being the most representative bats in the pellets $(0.4 \%$ for both, Table 1$)$. The marsupials of the order Didelphimorphia were represented by only two species, accounting for $2 \%$ of the examined sample, with both species being equally represented in the sample $(0.9 \%$, Table 1$)$.

The cumulative curves of species number constructed for the two datasets (all taxa vs non-volant) differed in their asymptotic behavior (Figure 1). The cumulative curve for all species did not stabilize at an asymptote throughout the 1739 individuals sampled in this study, exhibiting relatively large standard-deviations (1.61 to 2.11 species) around the expected mean number of species. This reduced precision in the richness estimates for all taxa was due to the number of singleton species (represented by a single individual), which in this case comprised the four bat species. When bats were excluded, the cumulative curve stabilized at an asymptote around 700 sampled specimens, resulting in very precise estimates of species richness (standard-deviations 0.06 to 0 species) throughout the first 1063 individuals of non-volant mammals sampled. No singleton species occurred among the non-volant taxa.

Six species represented in the owl pellets are new to the Restinga de Jurubatiba National Park (Figure 2). Calomys tener is recorded for the first time in the littoral of Rio de Janeiro state, while Necromys lasiurus is reported for the first time in restingas. Few species identifications were not
Table 1. Mammal species found in Barn owl pellets in the Restinga de Jurubatiba National Park, with their respective number of identified specimens (NISP) and minimal number of individuals (MNI), also provided as percent $(\%)$ of the total MNI.

\begin{tabular}{|c|c|c|c|}
\hline Taxa & NISP & MNI & $(\%)$ \\
\hline \multicolumn{4}{|l|}{ Rodentia } \\
\hline \multicolumn{4}{|l|}{ Cricetidae } \\
\hline Cerradomys goytaca Tavares et al., 2011 & 1810 & 654 & 37.6 \\
\hline Necromys lasiurus (Lund, 1840) & 385 & 139 & 8.0 \\
\hline Holochilus brasiliensis (Desmarest, 1819) & 180 & 64 & 3.7 \\
\hline Nectomys squamipes (Brants, 1827) & 125 & 57 & 3.3 \\
\hline Akodon cursor (Winge, 1887) & 19 & 12 & 0.7 \\
\hline Calomys tener (Winge, 1887) & 15 & 7 & 0.4 \\
\hline \multicolumn{4}{|l|}{ Muridae } \\
\hline Mus musculus Linnaeus, 1758 & 1889 & 688 & 39.6 \\
\hline Rattus rattus (Linnaeus, 1758) & 202 & 69 & 4.0 \\
\hline \multicolumn{4}{|l|}{ Caviidae } \\
\hline Cavia fulgida Wagler, 1831 & 19 & 8 & 0.5 \\
\hline \multicolumn{4}{|l|}{ Didelphimorphia } \\
\hline \multicolumn{4}{|l|}{ Didelphidae } \\
\hline Monodelphis aff. iheringi & 40 & 15 & 0.9 \\
\hline Marmosa paraguayana (Tate, 1931) & 39 & 15 & 0.9 \\
\hline \multicolumn{4}{|l|}{ Chiroptera } \\
\hline \multicolumn{4}{|l|}{ Phyllostomidae } \\
\hline Carollia perspicillata (Linnaeus, 1758) & 10 & 4 & 0.2 \\
\hline Glossophaga soricina (Pallas, 1766) & 1 & 1 & 0.1 \\
\hline Artibeus obscurus (Schinz, 1821) & 1 & 1 & 0.1 \\
\hline \multicolumn{4}{|l|}{ Vespertilionidae } \\
\hline Eptesicus sp. & 6 & 3 & 0.2 \\
\hline Lasiurus cinereus (P. Beauvois, 1796) & 3 & 1 & 0.1 \\
\hline Myotis nigricans (Schinz, 1821) & 1 & 1 & 0.1 \\
\hline 17 species & 4745 & 1739 & 100 \\
\hline
\end{tabular}

conclusive due to pending taxonomic issues regarding species diagnoses (e.g. Monodelphis aff. iheringi) or lack of taxonomically informative characters in the single skull fragment preserved in owl pellets (e.g. Eptesicus). Given the information compiled from previous mammal inventories in the Restinga de Jurubatiba National Park (Bergallo et al. 2004, Pessôa et al. 2010, Luz et al. 2011), the new occurrences of mammal species provided by owl pellets increase the local mammal richness to 44 species (Table 2). Owl pellet records accounted for $38.6 \%$ of the total mammal species richness, with $13.6 \%$ of this richness being exclusively recorded by this method (Table 2). When only rodents and marsupial species are considered, pellets are even more complementary, exclusively recording $31.6 \%$ of the species of these two groups in the Restinga de Jurubatiba National Park.

\section{Discussion}

The sample of 1739 individuals analyzed in this study is three times larger than the minimum sample sizes suggested by Torre et al. (2004) for reliable small mammal species richness estimates. Indeed, the cumulative curve of species richness obtained for non-volant species was very precise and asymptotic, as also obtained in other owl pellet studies (Rocha et al. 2011). Richness estimates become less precise only when bats are included, owing to their rarity in Barn Owl pellets (Escarlate-Tavares \& Pessôa 2005, Scheibler \& Christoff 2007). 


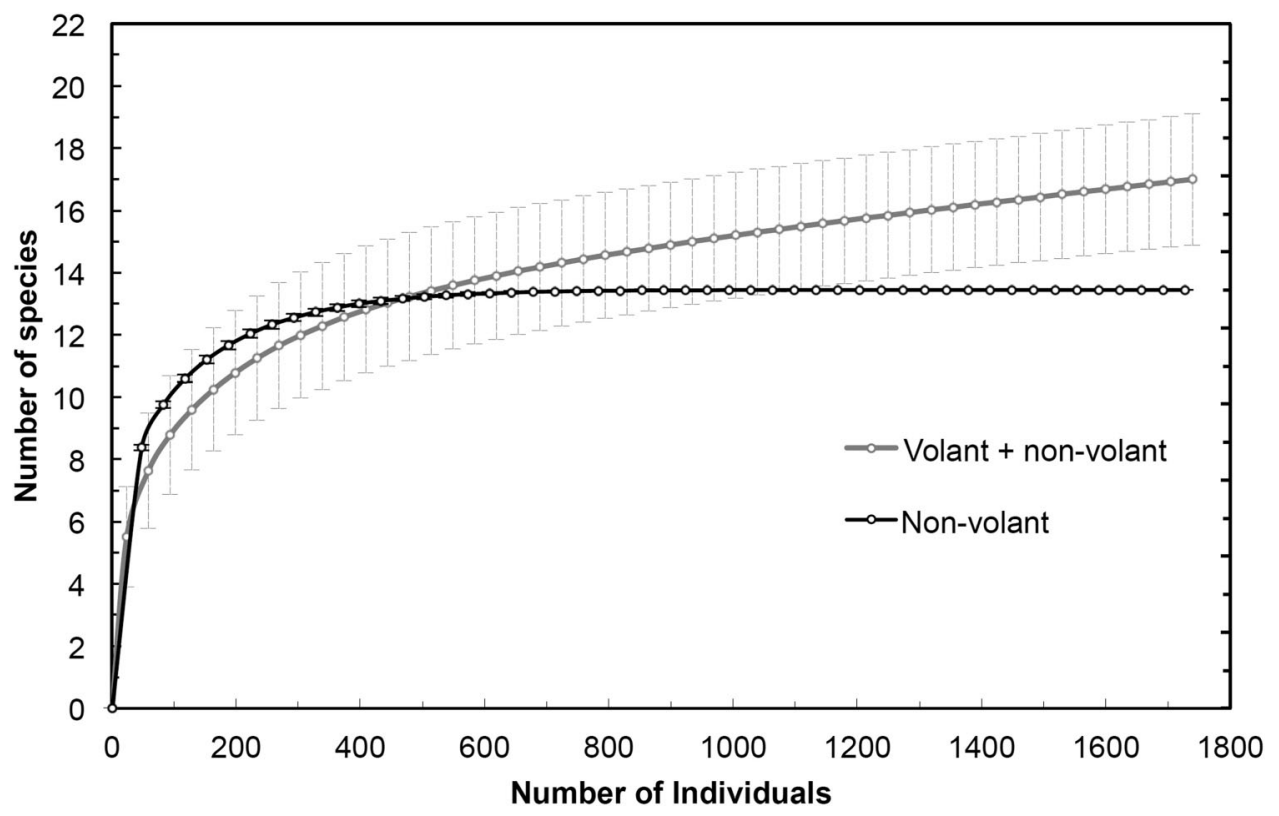

Figure 1. Cumulative curves of mean species richness of mammals recorded in Barn owl pelletsin the Restinga de Jurubatiba National Park including all (grey circles) and only non-volant species (black circles). Bars represent standard deviations.

The exotic mouse Mus musculus was the most frequently preyed species, despite its rarity in previous trapping studies in the study area (Bergallo et al. 2004, Pessôa et al. 2010), suggesting that the Barn owl hunts near farms, villages, roads and other altered restinga habitats found within the Restinga de Jurubatiba National Park. Our data suggests that the Barn owl also hunts extensively in preserved restinga habitats, given the high frequency of the endemic Goytacá rat Cerradomys goytaca among the preyed mammals. Cerradomys goytaca preferentially occupies open shrub formations that are broadly distributed in the study area, rarely occurring in forests or altered habitats where exotic species would be more common (Bergallo et al. 2004, Tavares et al. 2011). Barn owls usually travel distances of up to $1 \mathrm{~km}$ (seldom exceeding $2 \mathrm{~km}$ ) from the nesting site to foraging areas (Taylor 1994). Given that an area with a $1 \mathrm{~km}$ radius around the nesting site studied do not include habitats outside the coastal sandy plain, it's reasonable to assume that the local Barn owl foraging area is mostly included within the restinga, as also suggested by the high frequency of the endemic C. goytaca in the pellet sample.

The owl pellet data also revealed a number of new occurrences at local and regional scales, complementing information on the mammalian fauna composition in northern Rio de Janeiro littoral and filling distribution gaps. The record of the rodent Calomys tener, for instance, is new for restinga habitats in Southeastern Brazil and also represents the first occurrence of the species in the littoral of Rio de Janeiro state. This species inhabits dry and open vegetation formations in central Brazil, and its marginal records in Southeastern Brazil did not include littoral zones or coastal localities east to the Serra do Mar (Almeida et al. 2007; Bonvicino et al. 2010), despite its widespread occurrence in the coast of Southern Brazil (Quintela et al. 2014). The most coastal localities reported for this species in Southeastern Brazil were the municipalities of Santa Tereza, in Espírito Santo state, and Itapetininga, in São Paulo state (Bonvicino et al. 2010). Rocha et al. (2004b) listed C. tener among the mammals of Rio de Janeiro state, but no information on voucher-specimens, collecting localities or type of record was provided for this species, and its occurrence in the state was so far poorly known. We examined the collection of Museu Nacional and could confirm only one additional locality of occurrence for $C$. tener in Rio de Janeiro state, in the municipality of Comendador Levy Gasparian, bordering the state of Minas Gerais and far from the littoral (Figure 3). The two geographically distant records of $C$. tener reported here thus suggest that this species might be widespread in the state though rarely recorded in mammal inventories.

A second species reported for the first time in restingas was the rodent Necromys lasiurus. Nearby coastal records in grasslands and marshes in Campos dos Goytacazes (Rio de Janeiro state) and in semideciduous forests in Rio das Ostras (Rio de Janeiro state) already suggested the potential occupation of restingas by this species (Figure 3), given its widespread distribution throughout open areas (Bonvicino et al. 2008, D'Elía et al. 2008, Pessôa et al. 2010). Gatti et al. (2006) mentioned an unidentified species of the genus Necromys $(=$ Bolomys $)$ in the restingas of Paulo Cesar Vinha State Park, in Espírito Santo state, based on carnivore scat samples (Bolomys sp. in Gatti et al. 2006: Table 1). As the scat material was not referenced by voucher-specimens deposited in collections, we could not examine the Necromys sp. specimen analyzed by Gatti et al. (2006) to identify it at species level and preferred to maintain this record at genus level, as originally published. Therefore, the owl pellet material analyzed in this study is the first to provide unequivocal novel records of C. tener and N. lasiurus in restingas of Southeastern Brazil.

The replacement of original Atlantic forests by exotic grasslands in the last decades (Ribeiro et al. 2009) might have facilitated the recent dispersal of both $C$. tener and $N$. lasiurus to the littoral. On the other hand, the restingas biota in the northern Rio de Janeiro littoral shares similarities with the biotas of Cerrado and Caatinga as a putative result of past biogeographic connections among these three biotas 


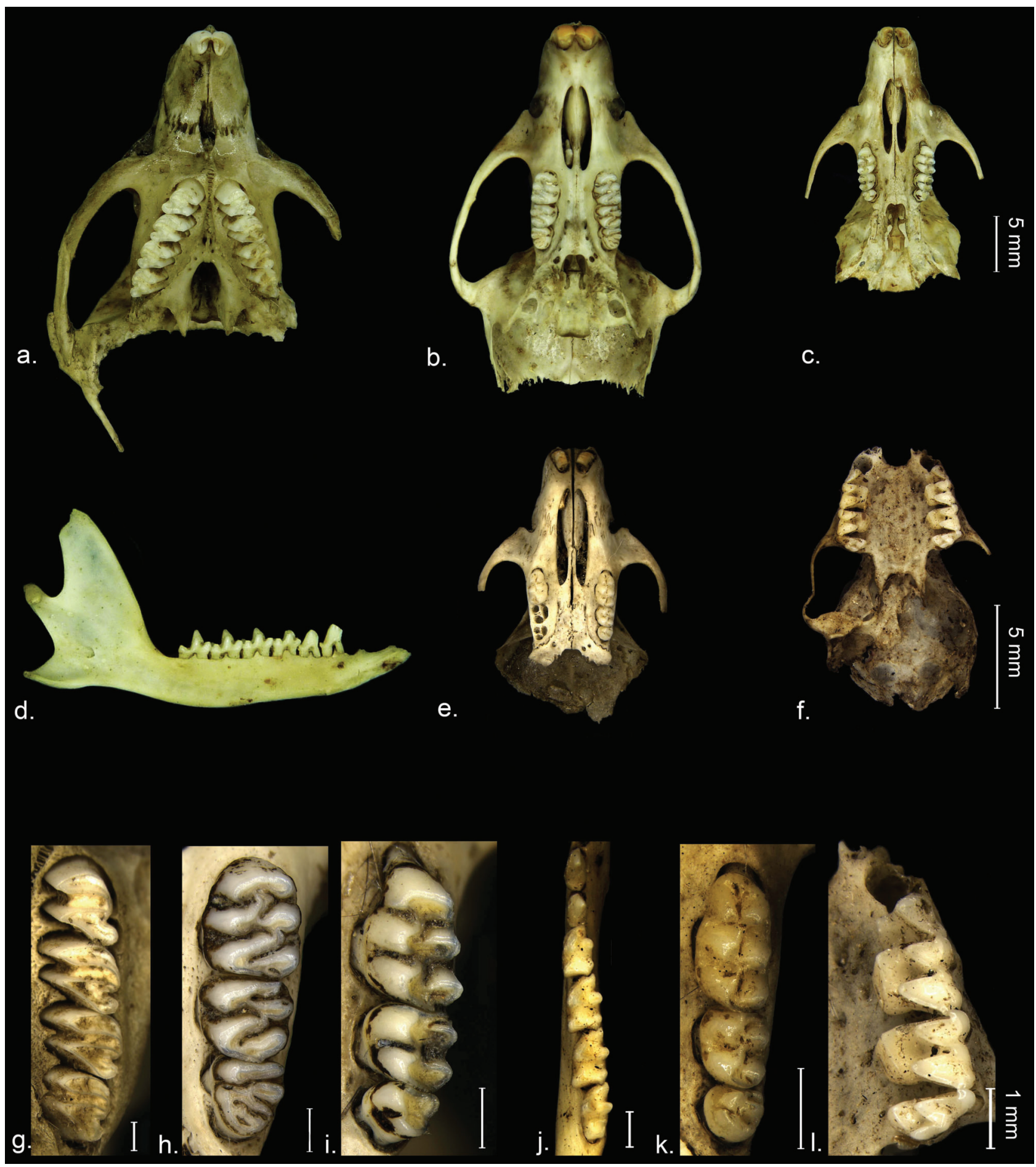

Figure 2. Skulls, mandible and respective molariform teeth of six new species records in the Restinga de Jurubatiba National Park found in Barn owl pellets: (a, g) Cavia fulgida, (b, h) Holochilus brasiliensis, (c, i) Necromys lasiurus (d, j) Monodelphis aff. iheringi, (e, k) Calomys tener and (f, l) Eptesicus sp.

(Tavares et al. 2011). Assuming this latter hypothesis, the occurrence of $C$. tener and $N$. lasiurus in restingas could be relictual and more ancient than that postulated by recent dispersion due to habitat modification. Genetic data would be needed to test among these hypotheses.

The aperea Cavia fulgida and the marsh rodent Holochilus brasiliensis also comprise novel records for the Restinga de
Jurubatiba National park, despite their wider distribution in the Atlantic forest (Bergallo et al. 2004, Bonvicino et al. 2008, Pessôa et al. 2010). These folivorous rodents are rarely attracted to conventionally baited live-traps (Alho 2005) and their preferred habitats include marshes and marginal aquatic vegetation, sites with difficult access for trapping but frequently used by the Barn owl for hunting, judging by the moderate frequencies of 
Table 2. Mammal species from the Restinga de Jurubatiba National Park, including information from previous inventory studies and from the owl pellet samples analyzed in the present study. Records in previous studies were based on live-trapping (Traps) and direct observation of animals or tracks (Obs). Sources: (1) Gonzaga \& Rajão (2001), (2) Bergallo et al. (2004), (3) Mangolin (2007), (4) Pessôa et al. (2010), (5) Luz et al. (2011), and this study.

\begin{tabular}{|c|c|c|c|}
\hline Taxa & Traps & Obs. & Owl pellets \\
\hline \multicolumn{4}{|l|}{ Didelphimorphia } \\
\hline \multicolumn{4}{|l|}{ Didelphidae } \\
\hline Caluromys philander (Linnaeus, 1758) & 2 & & \\
\hline Didelphis aurita (Wied-Neuwied, 1826) & 2,4 & & \\
\hline Marmosa paraguayana (Tate, 1931) & 2,4 & & present study \\
\hline Metachirus nudicaudatus (É. Geoffroy, 1803) & 4 & & \\
\hline Monodelphis aff. iheringi & & & present study \\
\hline Philander frenatus (Olfers, 1818) & 2,4 & & \\
\hline \multicolumn{4}{|l|}{ Cingulata } \\
\hline \multicolumn{4}{|l|}{ Dasypodidae } \\
\hline Dasypus novemcinctus Linnaeus, 1758 & & 2 & \\
\hline \multicolumn{4}{|l|}{ Pilosa } \\
\hline \multicolumn{4}{|l|}{ Myrmecophagidae } \\
\hline Tamandua tetradactyla (Linnaeus, 1758) & & 4 & \\
\hline \multicolumn{4}{|l|}{ Primates } \\
\hline \multicolumn{4}{|l|}{ Callitrichidae } \\
\hline Callithrix jacchus (Linnaeus, 1758) & & 2 & \\
\hline \multicolumn{4}{|l|}{ Rodentia } \\
\hline \multicolumn{4}{|l|}{ Cricetidae } \\
\hline Akodon cursor (Winge, 1887) & 2,6 & & present study \\
\hline \multicolumn{4}{|l|}{ Calomys tener (Winge, 1887) } \\
\hline Cerradomys goytaca Tavares et al. 2011 & 2,4 & & present study \\
\hline Holochilus brasiliensis (Desmarest 1819) & & & present study \\
\hline \multicolumn{4}{|l|}{ Necromys lasiurus (Lund, 1840) } \\
\hline Nectomys squamipes (Brants, 1827) & 2,4 & & present study \\
\hline Oxymycterus dasytrichus (Schinz, 1821) & 2,4 & & \\
\hline \multicolumn{4}{|l|}{ Muridae } \\
\hline Mus musculus Linnaeus, 1758 & 2 & & present study \\
\hline Rattus rattus (Linnaeus, 1758) & 2 & & present study \\
\hline \multicolumn{4}{|l|}{ Erethizontidae } \\
\hline Coendou spinosus (F. Cuvier, 1823) & & 2,4 & \\
\hline \multicolumn{4}{|l|}{ Caviidae } \\
\hline Hydrochoerus hydrochaeris (Linnaeus, 1766) & & 4 & \\
\hline Cavia fulgida Wagler, 1831 & & & present study \\
\hline \multicolumn{4}{|l|}{ Echimyidae } \\
\hline Trinomys eliasi (Pessôa and Reis, 1993) & 2 & & \\
\hline \multicolumn{4}{|l|}{ Chiroptera } \\
\hline \multicolumn{4}{|l|}{ Phyllostomidae } \\
\hline Artibeus lituratus (Olfers, 1818) & 2,5 & & \\
\hline Artibeus fimbriatus Gray, 1838 & 5 & & \\
\hline Artibeus obscurus (Schinz, 1821) & 5 & & present study \\
\hline Carollia brevicauda (Schinz, 1821) & 4 & & \\
\hline Carollia perspicillata (Linnaeus, 1758) & 2,5 & & present study \\
\hline Chiroderma vilossum Peters, 1860 & 2,5 & & \\
\hline Diaemus youngi (Jentink, 1893) & 2,5 & & \\
\hline Desmodus rotundus (É. Geoffroy, 1810) & 4 & & \\
\hline Glossophaga soricina (Pallas, 1766) & 2,5 & & present study \\
\hline Lophostoma brasiliense Peters, 1866 & 3,5 & & \\
\hline Platyrrhinus lineatus (É. Geoffroy, 1810) & 2,5 & & \\
\hline Platyrrhinus recifinus (Thomas, 1901) & 5 & & \\
\hline Uroderma magnirostrum Davis, 1968 & 5 & & \\
\hline \multicolumn{4}{|l|}{ Noctilionidae } \\
\hline Noctilio leporinus (Linnaeus, 1758) & 5 & & \\
\hline
\end{tabular}


Table 2. Continued.

\begin{tabular}{|c|c|c|c|}
\hline Taxa & Traps & Obs. & Owl pellets \\
\hline \multicolumn{4}{|l|}{ Vespertilionidae } \\
\hline Eptesicus sp. & & & present study \\
\hline Lasiurus cinereus (Palisot de Beauvois, 1796) & 5 & & present study \\
\hline Myotis nigricans (Schinz, 1821) & 5 & & present study \\
\hline \multicolumn{4}{|l|}{ Carnivora } \\
\hline \multicolumn{4}{|l|}{ Felidae } \\
\hline Puma yagouaroundi (É. Geoffroy, 1803) & & 2 & \\
\hline \multicolumn{4}{|l|}{ Canidae } \\
\hline Cerdocyon thous (Linnaeus, 1766) & & 2 & \\
\hline \multicolumn{4}{|l|}{ Mustelidae } \\
\hline Galictis cuja (Molina, 1782) & & 4 & \\
\hline \multicolumn{4}{|l|}{ Procyonidae } \\
\hline Potos flavus (Schreber, 1774) & & 1,4 & \\
\hline Procyon cancrivorus (G. Cuvier, 1798) & & 2,4 & \\
\hline
\end{tabular}

these taxa in the pellets (Table 1). Consequently, records of these species are highly dependent on the analyses of owl pellets and inventories exclusively based on live-trapping records will frequently fail to detect them (Escarlate-Tavares \& Pessôa 2005, Scheibler \& Christoff 2007, Bonvicino \& Bezerra 2003).

The record of the mouse opossum Monodelphis aff. iheringi is also unprecedented in restingas. Species of Monodelphis are commonly recorded in mammal inventories in Atlantic forest using pitfall traps (Moura et al. 2008), but the implementation of this trapping method in the study area yielded no samples this genus (Pessôa et al. 2010). This species might be locally rare or present only in semideciduous forests contiguous to the coastal sandy plain in the Restinga de Jurubatiba National Park.

The Vespertilionid bats Myotis nigricans and Lasiurus cinereus identified in the owl pellets had already been reported for the Restinga de Jurubatiba National Park using mistnets (Luz et al. 2011), but the genus Eptesicus is reported for the first time, despite its common occurrence in other restingas

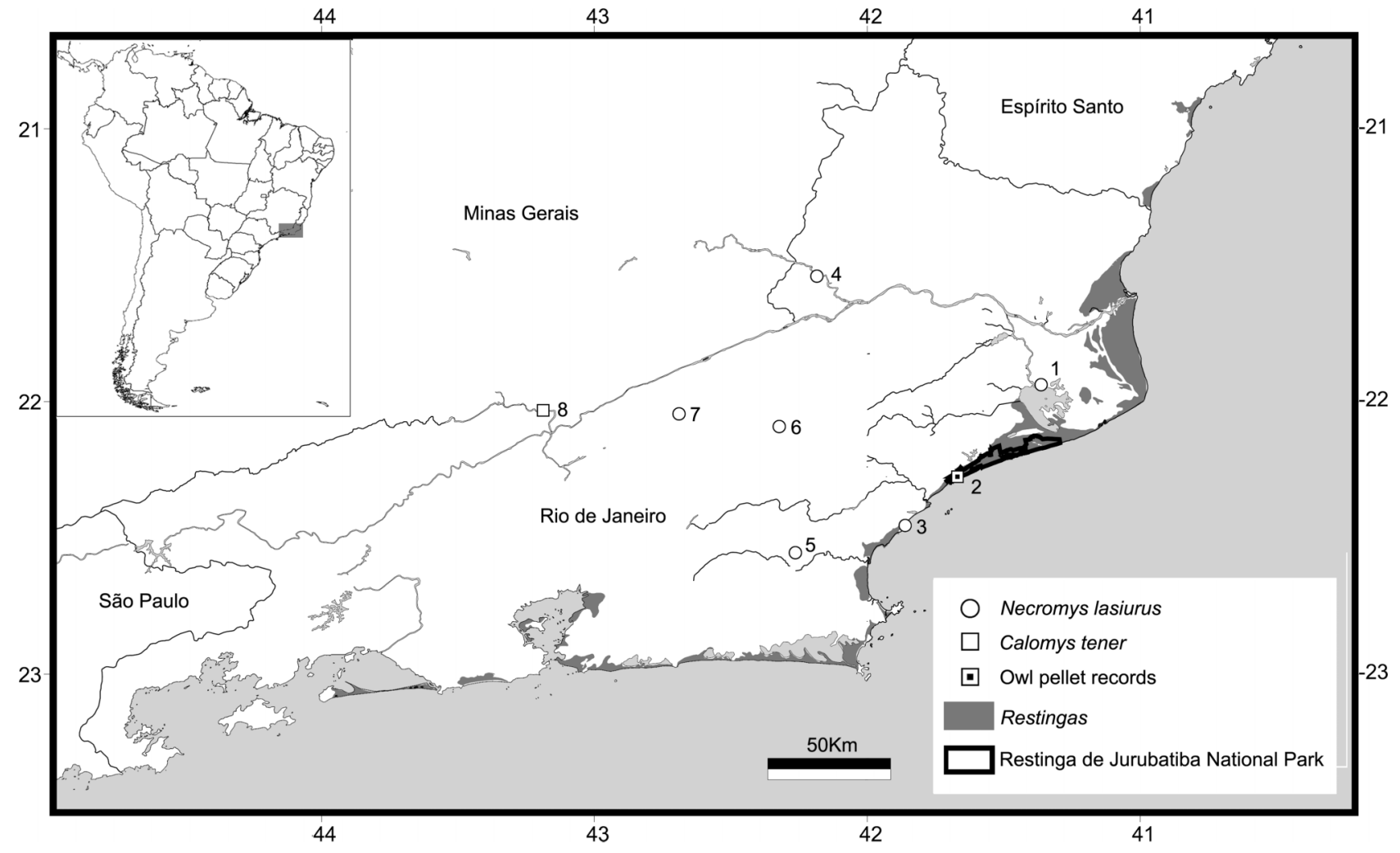

Figure 3. Collecting localities of voucher-specimens of Calomys tener and Necromys lasiurus in the Rio de Janeiro state: 1 - Lagoa Feia/Ponta Grossa, Campos dos Goytacazes (MN49734); 2 - Restinga de Jurubatiba National Park, Carapebus (NPM944, 953, 957, 960, 969, 973, 982); 3 - Mar do Norte, Rio das Ostras (MN24565-24567); 4 - Santo Antônio de Pádua (MN72744); 5 - Reserva Biológica de Poço das Antas, Silva Jardim (MN42882, 66174); 6 - Fazenda Independência, Cordeiro (MN75286, 75290); 7 - Sumidouro (MN24568, 43756); 8 - Fazenda Amazonas, Comendador Levy Gasparian (MN43888, 43893, 55710-55712). 
(Nogueira et al. 2010). Vespertilionids are rarely sampled by conventional methods as they forage for insects on open areas relying on high-sensitivity echolocation that may detect mistnets (Esbérard \& Bergallo 2008). The use of owl pellet records in this case should be combined with mistnet methods, even though bats are expected to be rarer than rodents in Barn owl prey items.

In summary, the records reported in this study corroborate the use of owl pellets as important complementary evidence for mammal inventories, especially regarding species that are difficult to detect by conventional live-trapping methods or are locally rare. The novel records also put the Restinga de Jurubatiba National Park as one of the richest coastal sandy plains for mammals (44 species) in Southeastern Brazil, second only to the Paulo César Vinha State Park (Venturini et al. 1996, Oprea et al. 2009) in Espírito Santo state. The updated local richness accounts for $23.8 \%$ of the mammals of Rio de Janeiro (Rocha et al. 2004b) and is nearly as high as those found in some well-preserved coastal humid montane areas, such as the Bocaina National Park (48 species, Delciellos et al. 2012). Given the current state of degradation of restingas in Rio de Janeiro state (Rocha et al. 2007), the high species richness found in the Restinga de Jurubatiba National Park is remarkable and might be related to its relatively large size, level of protection and variety of habitats, among other evolutionary and ecological factors. This local richness is suggestive of an important diversity hotspot in the northern Rio de Janeiro littoral, as already pointed out by bat, lizard and amphibian community comparisons (Oprea et al. 2009, Rocha et al. 2005), urging the expansion of the few existing protected areas in this region and the creation of new ones to protect the last restinga remnants in Southeastern Brazil.

\section{Acknowledgments}

We are grateful to Daniela Dias and Dayana Bolzan for the help with bat identifications, and indebted to João A. Oliveira for the access to the Museu Nacional mammal collection. A. Caccavo-Araujo, M. S. Xavier, M. Atta, T. Oliveira, T. Scarpini and V. A. O. S. Ferrão helped in the fieldwork. Two anonymous reviewers gave important suggestions on previous versions of the manuscript. Financial support was provided by CNPq (Long Term Ecological Research program - PELD, Site 5), FAPERJ (processes E26/110.605/2009, E26/112.701/2012 and E26/141.338/2013) and CAPES, through a Master graduate fellowship to H. M. Lemos. ICMBio and IBAMA granted access and provided research permits (no. 17418 and 17496) to work at the Restinga de Jurubatiba National Park.

\section{References}

ALHO, C.J.R. 2005. The pantanal. In The world's largest wetlands ecology and conservation (L.H. Fraser \& A.K. Pauls, eds.). Cambridge University Press, New York, p. 203-271.

ALMEIDA, F.C., BONVICINO, C.R. \& CORDEIRO-ESTRELA, P. 2007. Phylogeny and temporal diversification of Calomys (Rodentia, Sigmodontinae): implications for the biogeography of an endemic genus of the open/dry biomes of South America. Mol. Phylogenet. Evol. 42(2): 449-466, http://dx.doi.org/10.1016/j. ympev.2006.07.005

BERGALLO, H.G., MARTINS-HATANO, F., RAÍCES, D., RIBEIRO, T.T.L., ALVES, A.G., LUZ, J.L., MANGOLIN, R. \& MELLO, M.A.R. 2004. Os mamíferos da restinga de Jurubatiba.
In Pesquisas de Longa Duração na Restinga de Jurubatiba: ecologia, história natural e conservação (C.F.D. Rocha, F.A. Esteves \& F.R. Scarano, eds.). RiMa, São Carlos, p. 215-230.

BERGALLO, H.G., ESBÉRARD, C.E.L., GEISE, L., GRELLE, C.E.V., VIEIRA, M.V., GONÇALVES, P.R., PAGLIA, A. \& ATTIAS, N. 2009. Mamíferos endêmicos e ameaçados do Estado do Rio de Janeiro: diagnóstico e estratégias para a conservação. In Estratégias e ações para a conservação da biodiversidade no Estado do Rio de Janeiro (H.G. Bergalo, E.C.C. Fidalgo, C.F.D. Rocha, M.C. Uzêda, M.B. Costa, M.A.S. Alves, M. Van Sluys, M.A. Santos, T.C.C. Costa \& A.C.R. Cozzolino, eds.), Instituto Biomas, Rio de Janeiro, p. 209-219.

BONVICINO, C.R. \& BEZERRA, A.M.R. 2003. Use of Regurgitated Pellets of Barn Owl (Tyto alba) for Inventorying Small Mammals in the Cerrado of Central Brazil. Stud. Neotrop. Fauna E. 38(1): 1-5, http://dx.doi.org/10.1076/snfe.38.1.1.14030

BONVICINO, C.R., OLIVEIRA, J.A. \& D'ANDREA, P.S. 2008. Guia dos Roedores do Brasil, com chaves para gêneros baseadas em caracteres externos. Rio de Janeiro: centro Pan-Americano de Febre Aftosa - OPAS/OMS, Rio de Janeiro.

BONVICINO, C.R., OLIVEIRA, J.A., \& GENTILE, R. 2010. A new species of Calomys (Rodentia: Sigmodontinae) from Eastern Brazil. Zootaxa. 2336: 19-25.

CERQUEIRA, R. 2000. Biogeografia das restingas. In Ecologia de restingas e lagoas costeiras. (F.A. Esteves \& L.D. Lacerda, eds.). Rio de Janeiro: Computer \&Publish. p. 65-75. NUPEM/UFRJ, Rio de Janeiro.

COLWELL, R.K., CHAO, A., GOTELLI, N.J., LIN, S.Y., MAO, C.X., CHAZDON, R. \& LONGINO, J.T. 2012. Models and estimators linking individual-based and sample-based rarefaction, extrapolation and comparison of assemblages. J. Plant. Ecol-UK 5(1):3-21.

COLWELL, R.K. 2013. EstimateS: Statistical estimation of species richness and shared species from samples. Version 9.

DELCIELlOS, A.C., NOVAES, R.L.M., LOGUERCIO, M.D.C., GEISE, L., SANTORI, R.T., SOUZA, R.D.F., PAPI, B.S., RAÍCES D., VIEIRA, N.R. FELIX S., DETOGNE N., SILVA, C.C.S., BERGALlO, H.G. \& ROCHA-BARBOSA, O. 2012. Mammals of Serra da Bocaina National Park, state of Rio de Janeiro, southeastern Brazil. Check List, 8(4): 675-692.

D'ELÍA, G., PARDIÑAS, U.F.J., JAYAT, J.P. \& SALAZAR-BRAVO, J. 2008. Systematics of Necromys (Rodentia, Cricetidae, Sigmodontinae): species limits and groups, with comments on historical biogeography. J. Mammal. 89(3): 778-790, http://dx.doi.org/10.1644/ 07-MAMM-A-246R 1.1

ESBÉRARD, C.E.L. \& BERGALLO, H.G. 2008. Influência do esforço amostral na riqueza de espécies de morcegos no sudeste do Brasil. Rev. Bras. Zool. 25(1): 67-73, http://dx.doi.org/10.1590/ S0101-81752008000100010

ESCARLATE-TAVARES, F. \& PESSÔA, L.M. 2005. Bats (Chiroptera, Mammalia) in Barn Owl (Tyto alba) pellets in northern Pantanal, Mato Grosso, Brazil. Mastozoología Neotropical 12(1): 61-67.

ESTEVES, F.D.A. 2011. Do índio Goytacá à economia do petróleo: uma viagem pela história e ecologia da maior restinga protegida do Brasil. Essentia Editora, Campo dos Goytacazes.

GATTI A., BIANCHI R., ROSA C.R.X., MENDES S.L. 2006. Diet of two sympatric carnivores, Cerdocyon thous and Procyon cancrivorus, in a restinga area of Espirito Santo State. Brazil. J. Trop. Ecol. 22: 227-230.

INMET. Instituto Nacional de Meteorologia. INMET - Clima Disponível em: http://www.inmet.gov.br/html/clima.php. (acesso em 04/08/2014)

LÓPEZ-GONZÁLEZ, C. 2005. Murciélagos de Paraguay. Biosfera, Sevilla.

LUZ, J.L., MANGOLIN, R., ESBÉRARD, C.E.L. \& BERGALLO, H.G. 2011. Morcegos (Chiroptera) capturados em lagoas do Parque Nacional da Restinga de Jurubatiba, Rio de Janeiro, Brasil. Biota Neotrop. 11 (4):161-168. http://www.biotaneotropica.org. 
br/v11n4/pt/abstract?inventory + bn01011042011, http://dx.doi.org/ 10.1590/S1676-06032011000400016

LYMAN, R.L. 2008. Quantitative Paleozoology. Cambridge University Press, New York.

MARTINS-HATANO, F., RAÍCES, D.S., GAZETA, G.S., SERRA-FREIRE, N.M., GETTINGER, D., BERGALLO, H.G. 2011. Community composition of laelapine mites (Acari: Laelapidae) associated with the nests and fur of Cerradomys subflavus (Wagner, 1842). J Nat Hist. 45(27):1679-1688.

MOOJEN, J. 1943. Captura e preparação de pequenos mamíferos para coleções de estudo. Imprensa Nacional, Rio de Janeiro.

MOURA, M.C., GRELLE, C.E.V. \& BERGALLO, H.G. 2008. How does sampling protocol affect the richness and abundance of small mammals recorded in tropical forest? An example from the Atlantic Forest. Neotropbiol Cons. 3(2):51-58.

NOGUEIRA, M.R., MAZUREC, A.P. \& PERACCHI A.L. 2010. Morcegos em restingas: lista anotada e dados adicionais para o norte fluminense, sudeste do Brasil (Mammalia, Chiroptera). In Mamíferos de restingas e manguezais da Brasil (L.M. Pessoa, W.C. Tavares \& S. Siciliano, eds) Sociedade Brasileira de Mastozoologia/Museu Nacional, Rio de Janeiro, p. 75-93.

OPREA, M., ESBÉRARD, C.E.L., VIEIRA, T.B., PIMENTA, P., BRITO, D. \& DITCHFIELD, D. 2009. Bat community species richness and composition in a restinga protected area in Southeastern. Brazil. Braz. J. Biol. 69(4): 631-637.

PESSÔA, L.M., TAVARES, W.C. \& GONÇALVES, P.R. 2010. Mamíferos das Restingas do Macrocompartimento Litorâneo da Bacia de Campos, Rio de Janeiro. In Mamíferos de restingas e manguezais da Brasil. (L.M. Pessoa, W.C. Tavares \& S. Siciliano, eds) Sociedade Brasileira de Mastozoologia/Museu Nacional, Rio de Janeiro, p. 56-78.

PAGLIA, A.P., FONSECA, G.A.B., RYLANDS, A.B., HERRMANN, G., AGUIAR, L.M.S., CHIARELLO, A.G., LEITE, Y.L.R., COSTA, L.P., SICILIANO, S., KIERULFF, M. C.M., MENDES, S.L., TAVARES, V.C., MITTERMEIER, R.A. \& PATTON, J.L. 2012. Annotated Checklist of Brazilian Mammals. 2 ed. Conservação Internacional do Brasil, Belo Horizonte.

QUINTELA, F.M., DA SILVEIRA, E.C, DELLAGNESE, D.G., \& CADEMARTORI, C.V. 2014. Calomys tener (Winge, 1887) (Rodentia: Cricetidae: Sigmodontinae): Filling gaps. Check List 10(3): 650-654, http://dx.doi.org/10.15560/10.3.650

RAÍCES, D.S.L. \& BERGALLO, H.G.2010. Diet and seed dispersion of the crab-eaten fox, Cerdocyon thous (Linnaeus, 1766). In Restinga de Jurubatiba National Park, Rio de Janeiro State, Brazil. Neotrop. Biol. Cons. 5(1):24-30.

RIBEIRO, M.C., METZGER, J.P., MARTENSEN, A.C., PONZONI, F.J. \& HIROTA, M.M. 2009. The Brazilian Atlantic Forest: How much is left, and how is the remaining forest distributed? Implications for conservation. Biol. Cons. 142(6):1141-1153, http:// dx.doi.org/10.1016/j.biocon.2009.02.021

ROCHA, C.F.D., BERGALLO, H.G., Alves, M.A.S. \& VAN SLUYS, M. 2004. A Restinga de Jurubatiba e a conservação dos ambientes de restinga do Estado do Rio de Janeiro. In Pesquisas de longa duração na Restinga de Jurubatiba - Ecologia, história natural e conservação (C.F.D. Rocha, F.A. Esteves, F.R. Scarano, eds). RiMa, São Carlos, p. 341-352.

ROCHA, C.F.D., BERGALLO, H.G., POMBAL J.R., H.G, GEISE, L., VAN SLUYS, M, FERNANDES, R. \& CARAMASCHI, U. 2004b. Lista de anfíbios, répteis e mamíferos do Estado do Rio de Janeiro, Sudeste do Brasil. Publicações avulsas do Museu Nacional, 104: 1-24.

ROCHA, C.F.D., VAN SLUYS, M, BERGALLO, H.G \& ALVES, M.A.S. 2005. Endemic and threatened tetrapods in the restingas of the biodiversity corridors of Serra do Mar and of the Central da Mata Atlântica in eastern Brazil. Braz. J. Biol. 65(1):159-168, http://dx.doi.org/10.1590/S1519-69842005000100019

ROCHA, C.F.D., BERGALLO, H.G., VAN SLUYS, M, ALVES, M.A.S \& JAMEL, C.E. 2007. The remnants of restinga habitats in the brazilian Atlantic Forest of Rio de Janeiro state, Brazil: Habitat loss and risk of disappearance. Braz. J. Biol. 67(2):263-273, http://dx.doi.org/10.1590/S1519-69842007000200011

ROCHA, R.G., FERREIRA, E., LEITE, Y.L.R., FONSECA, C. \& COSTA, L.P. 2011. Small mammals in the diet of Barn owls, Tyto alba (Aves: Strigiformes) along the mid-Araguaia River in central Brazil. Zoologia. 28(6): 709-716, http://dx.doi.org/10.1590/ S1984-46702011000600003

SCHEIBLER, D.R. \& CHRISTOFF, A.U., 2007. Habitat associations of small mammals in southern Brazil and use of regurgitated pellets of birds of prey for inventorying a local fauna. Braz. J. Biol. 67(4): 619-625, http://dx.doi.org/10.1590/S1519-69842007000400005

STEPPAN, S.J. 1995. Revision of the tribe Phyllotini (Rodentia: Sigmodontinae) with a phylogenetic hypothesis for the Sigmodontinae. Fieldiana Zool. 80:1-112.

TAVARES, W.C., PESSÔA, L.M. \& GONÇALVES, P.R. 2011. A new species of Cerradomys from coastal Sandy plains of southeastern Brazil (Cricetidae: Sigmodontinae). J. Mammal. 92(3): 645-658, http://dx.doi.org/10.1644/10-MAMM-096.1

TAYLOR, I. 1994. Barn Owls: predator-prey relationships and conservation. 2 ed. Cambridge University Press, Cambridge.

TORRE, I., ARRIZABALAGA, A. \& FLAQUER, C. 2004. Three methods for assessing richness and composition of mammal communities. J. Mammal. 85(3):524-530, http://dx.doi.org/10.1644/ BJK-112

UMETSU, F., NAXARA, L. \& PARDINI, R. 2006. Evaluating the efficiency of pitfall traps for sampling small mammals in the neotropics. J Mammal. 87(4):757-765.

VENTURINI, A.C., OFRANTI, A.M.S., VAREJÃO, J.B.M. \& PAZ, P.R. 1996. Aves e mamíferos da restinga: Parque Estadual Paulo César Vinha, Setiba, Guarapari, ES. Secretaria de Estado de Desenvolvimento Sustentável, Vitória.

VOSS, R.S. \& CARLETON, M.D. 1993. A new genus for Hesperomys molitor Winge and Holochilus magnus Hershkovitz (Mammalia, Muridae) with an analysis of its phylogenetic relationships. Am. Mus. Novit. 3085.

VOSS, R.S. \& JANSA, S.A. 2009. Phylogenetic Relationships and Classification of Didelphid Marsupials, an Extant Radiation of New World Metatherian Mammals. Bull. Am. Mus. Nat. Hist. 322. 